\title{
First description of the larva of Psaironeura, based on specimens of $P$. angeloi from Costa Rica (Odonata: Coenagrionidae: Protoneurinae), with a key to the genera of Central American Protoneurinae
}

\author{
Jareth Román-Heracleo (Di) ${ }^{\mathrm{a} *}$, Rodolfo Novelo-Gutiérrez (ib ${ }^{\mathrm{b}}$ and Monika Springer (iD) \\ ${ }^{a}$ Sistema de Estudios de Posgrado en Biología,Universidad de Costa Rica, San José, Costa Rica; \\ ${ }^{b}$ Instituto de Ecología, A.C. Red de Biodiversidad y Sistemática, Xalapa, Mexico; ${ }^{c}$ Museo de Zoología, \\ Escuela de Biología \& CIMAR, Universidad de Costa Rica, San José, Costa Rica
}

(Received 20 January 2020; final version received 3 April 2020)

\begin{abstract}
The larva of Psaironeura is formally described for the first time, based upon reared specimens of Psaironeura angeloi from the Tirimbina Biological Reserve, Sarapiquí, Heredia Province, Costa Rica. Detailed illustrations are also provided. The larva is characterized by a slender dark brown body, premental setae $2+1$, six palpal setae, male cerci globose, and caudal lamellae markedly slender, 3.5-4 times longer than wide, with tips bi- or trilobated.
\end{abstract}

Keywords: Neotropical region; Central America; Zygoptera; exuviae; reared specimens; taxonomy; damselflies; dragonfly

\section{Introduction}

Protoneurinae (Coenagrionidae) is a small subfamily of Neotropical damselflies with 15 genera and 123 species (Garrison, von Ellenrieder, \& Louton, 2010; Pessacq \& Costa, 2010; Pimenta, Pinto, \& Takiya, 2019; Tennessen, 2016). They are found associated with pools with abundant leaf litter, and floating debris in small rivers and creeks, as well as in seeps from peaty substrate at the forest edge, at low to middle elevations (Esquivel Herrera, 2005; Pinto \& Kompier, 2018). Some species are tolerant to disturbed habitats (Pinto \& Kompier, 2018). Psaironeura Williamson, 1915 is a small genus distributed from southern Mexico to Peru and NW Brazil, although P. tenuissima (Selys, 1886) has been found in Midwest Brazil (Vilela, pers. comm.), with five species described to date (Tennessen, 2016). From Southeastern Mexico and Central America three species of Psaironeura have been reported: P. angeloi Tennessen, 2016, P. remissa (Calvert, 1903) and P. selvatica Esquivel, 1993. To date, none of the larvae of Psaironeura have been formally described, although the larva of $P$. tenuissima has been previously keyed and illustrated (Lozano, Muzón, Anjos-Santos, \& Pessacq, 2018; Neiss \& Hamada, 2014; Pessacq, Muzón, \& Neiss, 2018). In this paper, we describe the last stadium larva of P. angeloi based

*Corresponding author. Email: romanjareth@gmail.com 
upon two exuviae (reared, male and female), and six F-0 larvae. This represents the first formal description of the larval stage of Psaironeura.

\section{Methods}

Fully developed larvae (F-0) were collected with an aquatic net and transported to the laboratory for rearing. Emerged adults were maintained alive for a few days and preserved after death in $95 \%$ ethanol, together with their exuviae. Additional larvae preserved in $95 \%$ ethanol were also examined. The descriptions and measurements (in $\mathrm{mm}$ ) were made using a Nikon SMZ745 stereomicroscope (Chiyoda-ku, Tokyo, Japan) with a calibrated ocular micrometer. Photographs of morphology were taken with a Nikon SMZ25 stereomicroscope and its mounted Nikon DS-U3 camera and processed with the program NIS elements AR version 4.5 (Laboratory Imaging s.r.o, Praha, Czech Republic). Mandible nomenclature follows Watson (1956) and labium nomenclature follows Corbet (1953).

Abbreviations are as follows: AL, abdomen length (without caudal lamella); CeL, cerci length; F-0, final stadium; FgL, female gonapophyses length; MgL, male gonapophyses length; MsfL, mesothoracic femur length; MtfL, metathoracic femur length; MWh, maximum width of head; Pfl: prothoracic femur length; S1-10, abdominal segments; TL, total length (including caudal lamellae); MZUCR, Museo de Zoología, Universidad de Costa Rica; IEXA, Colección Entomológica "Miguel Angel Morón Ríos" del Instituto de Ecología, A.C.

\section{Final stadium larva of Psaironeura angeloi}

(Figures 1-5)

\section{Specimens examined}

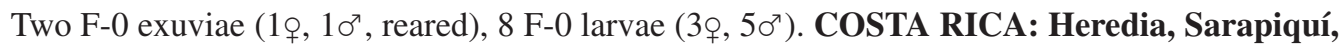
La Virgen, Tirimbina Biological Reserve (10.4177 N; 84.1194 W; elevation 162 m); 27 April

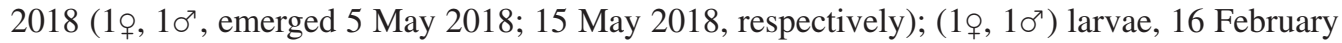
2019, $\left(2\right.$ o , 4 $\left.4 \sigma^{7}\right)$ larvae. 15 April 2019 J. Román-Heracleo and Yanil Bravo-Méndez leg. Two larvae $\left(1 \circ, 10^{7}\right)$, deposited at IEXA, all other in MZUCR.

\section{Description}

Exuviae and fully developed larvae mostly dark brown, small and slender, with a posterolateral, nipple-shaped tubercle to each side of pronotum, tips of lateral lamellae (paraprocts) bilobate, tip of central lamella (epiproct) tri-lobate (Figure 1).

Head. Subpentagonal, almost twice as wide as long, wider than thorax and abdomen (Figures 1, 2a). Labrum ventral margin concave at middle, with eight small spiniform setae; clypeus with brown spot at middle, clypeus brown with small yellow spots and dots spread on surface, some long and short delicate setae on distal surface, basal half glabrous; frons slightly convex dorsally, vertex flat with two dark brown spots on each side of midline and close to lateral ocelli. Occipital margin (Figure 2a) widely concave mesally; occipital lobes rounded, with two transversal rows of claviform setae, the dorsal row with eight claviform setae, the ventral one with six claviform setae. Antennae (Figure 2b) filiform, 7-segmented, scape barrel-shaped, pedicel fusiform, both yellow; flagellomeres elongated, 3rd antennomere the longest with basal third brown, remainder yellowish, 4th and 6th mostly brown, 5th and 7th yellow, size proportions of antennomeres: 


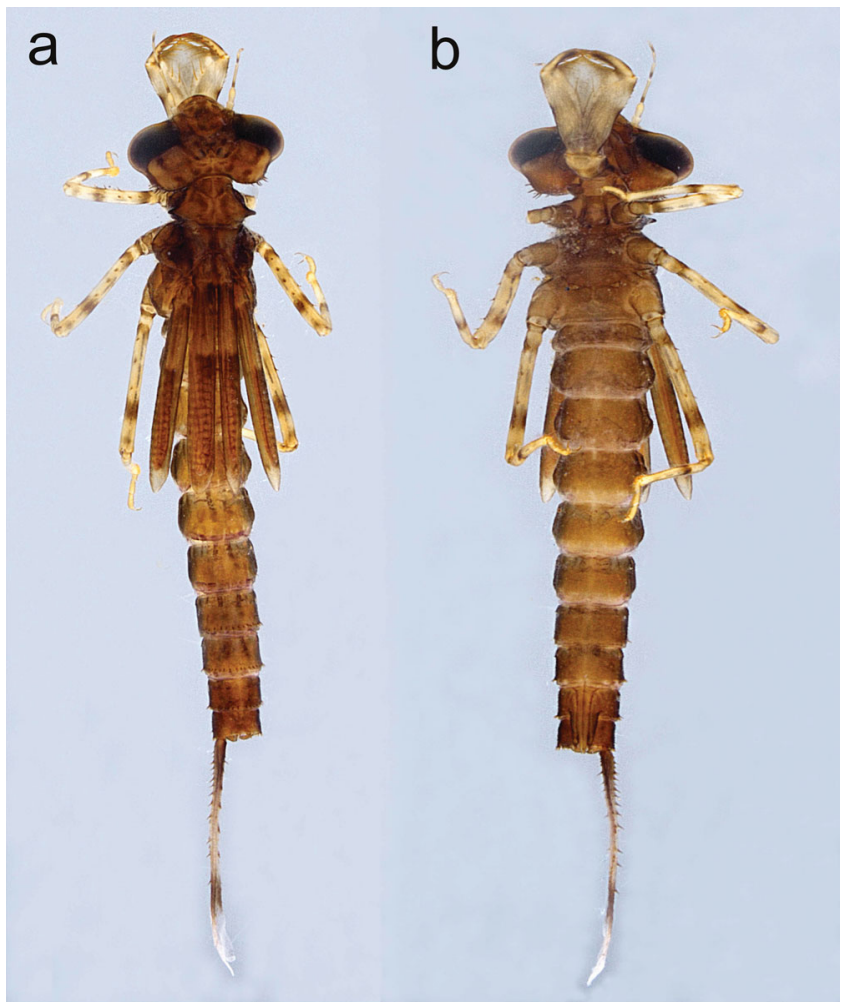

Figure 1. Psaironeura angeloi, female. Habitus dorsal of the F-0 larva.

$0.50,0.50,1.0,0.70,0.50,0.40,0.20$. Compound eyes large, slightly wider than long, laterally prominent. Mandibles (Figure 2c) with formula: R 1234 y a+b / L 1'1234 y a b, b=a. Maxilla's (Figure 2d) galeolacinia with six teeth, three dorsal teeth slightly incurved, similar length and robustness, with a basal row of setae, three ventral teeth of different size and robustness, the apical tooth more developed and stout, size proportions: apical tooth 1.0, median one 0.40 , basal tooth a small spine, with a basal row of stiff setae which increase suddenly in size and robustness apically, maxillary palp gently incurved, ending in a stout spine, with long setae on the external surface. Ventral pad of hypopharynx subpentagonal, anterior margin convex, surface glabrous, three long and fine setae on each anterolateral corner. Labium: Prementumpostmentum articulation reaching posterior margin of procoxae; prementum (Figure 2e) longer than wide, subrhomboidal, lateral margins slightly concave, widely divergent apically, laterodorsal margin with a row of 6-7 (usually 6) spiniform setae, with two brown spots at each side, one at middle and another one subapical; ligula moderately projected, mesally convex, finely serrulate on distal margin, with a minute submarginal spine to each side of midline; 2 premental setae to each side of midline. Labial palp (Figure 2e, f) with 6 long setae, its apical lobe divided into a squarely truncate dorsal branch which has the distal margin with three small inferior teeth similar in size and robustness, and four superior minute denticles, and a ventral branch with a well-developed end hook, slightly downcurved (Figure 2f); internal margin of palp finely serrate; movable hook scarcely a half the length of labial palp, sharply pointed.

Thorax. Pleura blackish-brown. Pronotum subtrapezoidal (Figures 1, 2a), yellowish-brown with dark brown spots, borders dark brown, dorsal surface slightly convex, lateral margins 


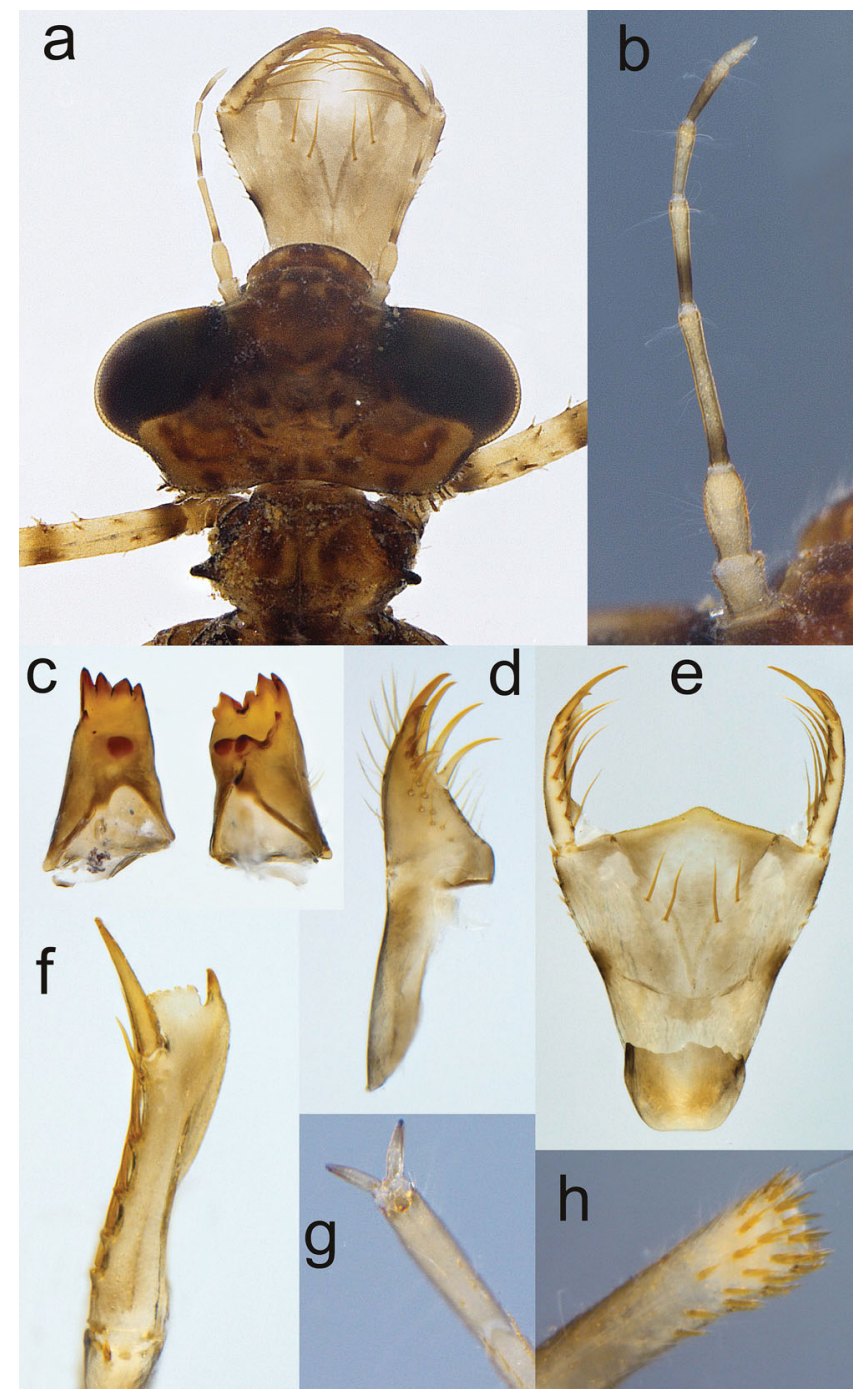

Figure 2. Psaironeura angeloi details of larval morphology. (a) Head of male, dorsal view; (b) right antenna, dorsal view; (c) mandibles, ventrointernal view; (d) right maxilla, ventral view; (e) dorsal view of prementum; (f) right labial palp, dorsolateral view; (g) pretarsal claws and pulvilliform empodium; (h) distal end of tibia, internal view.

concave, gradually diverging caudad to form a large, conspicuous, nipple-shaped, posterolateral tubercle at each side (Figure 2a); posterolateral margin with two robust setae on each side of middle line. Pterothorax dark brown; anterior and posterior wing sheaths reaching the posterior margin of S6 (Figure 1), with abdomen not distended. Legs long (when fully extended, posterior margin of hind tibiae surpassing posterior margin of S10), slender, mostly pale with brown bands on femora and tibiae. Femora laterally compressed with a dorsal row of concave, roundly pointed setae intermingled with long and very fine setae, with two dark brown bands, one basal band and the other one subapical. Tibiae with a dark brown band almost at midlength and a subapical ambarine band, a dorsal row of delicate long and short setae, increasing apically in abundance, distal third with abundant tridentate setae on posterior surface (Figure $2 \mathrm{~h}$ ). Tarsi yellowish, with two ventral rows of spiniform setae, with delicate setae on dorsal surface, claws simple, with a pulvilliform empodium (Figure $2 \mathrm{~g}$ ). 


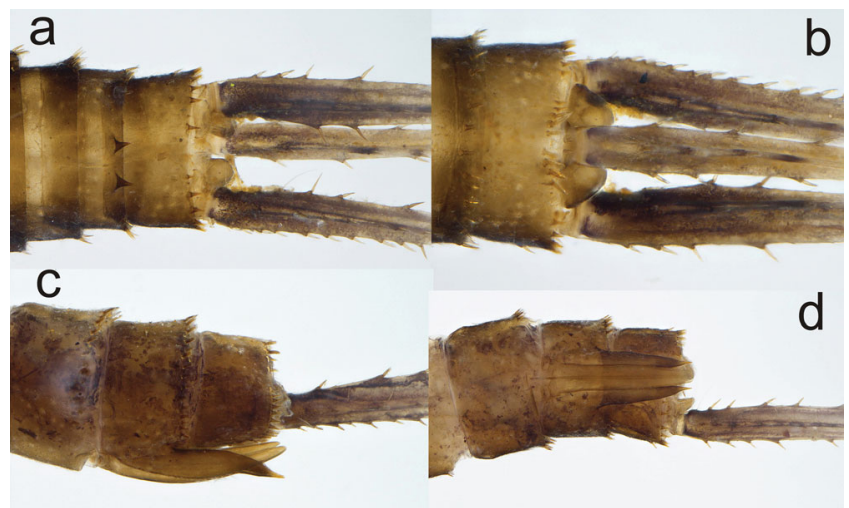

Figure 3. Psaironeura angeloi, S8-10. (a) Male gonapophyses and cerci, ventral view; (b) female gonapophyses, lateral view; (c) male cerci, dorsal view; (d) female gonapophyses, ventral view (two caudal lamellae detached).

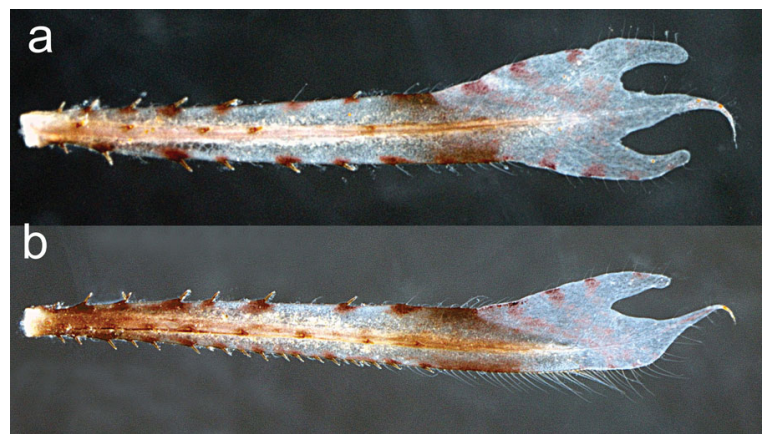

Figure 4. Psaironeura angeloi, caudal lamellae, left lateral view. (a) Epiproct; (b) paraproct.

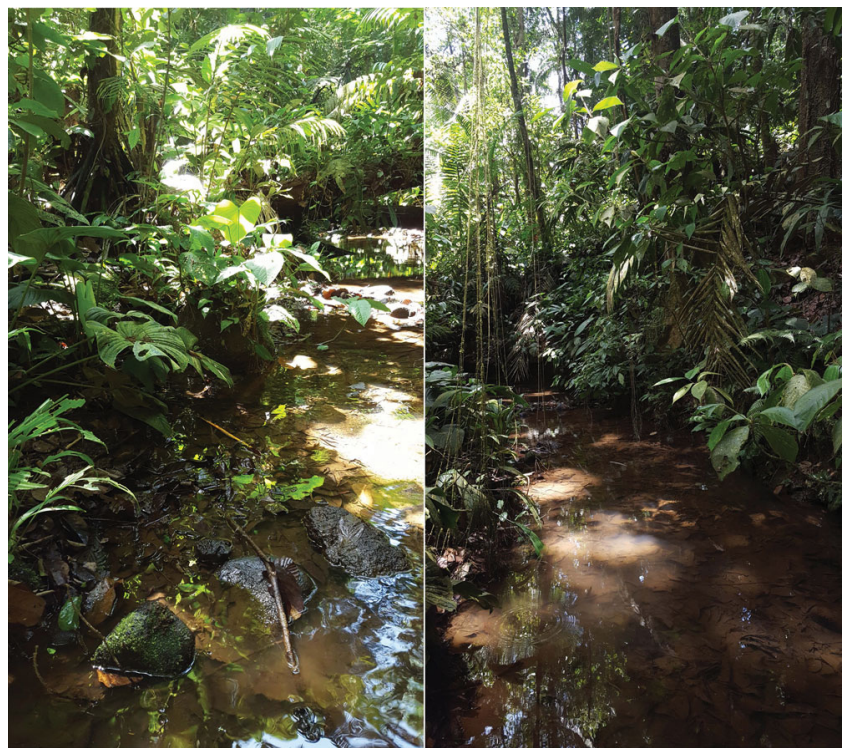

Figure 5. Habitat of Psaironeura angeloi. Sarapiquí, Tirimbina Biological Reserve. Photos by Jareth Román-Heracleo. 
Abdomen. Dark brown at sides, lighter dorsally, with minute yellow dots (Figure 1) gradually narrowing caudad, S1-6 with lateral margins slightly convex, S7-10 with lateral margins straight; S1-6 mostly bare, S7-10 with minute whitish setae on its surface; posterior margin of S7-10 with a row of stout, concave, roundly pointed setae, S10 with three larger concave, roundly pointed setae on each side of middorsal line. Sternites 1-10 with very minute whitish setae which are more abundant posteriorly. Male gonapophyses (Figure 3a) short, conical, deep dark brown, surpassing well beyond the posterior margin of sternite 9, divergent in ventral view, sharply pointed, their bases separated from each other by more than one fourth the length of gonapophyses. Female gonapophyses (Figure 3c, d) surpassing well beyond the posterior margin of sternite 10, internal and external valvae same length, external valve sharply pointed, with a ventral row of setae, internal valve roundly tipped, smooth. Lateral lamellae (Figure 4) long, slender, slightly and gradually widening caudad, the basal half approximately triquetral, remainder rather planar; the basal $0.70-0.75$ strongly sclerotized and darker, with a strong carina on both external and internal, surfaces, with a clearly marked diagonal nodus, the apical $0.25-0.30$ membranous, with three grayish-violet tranversal bands, and tips bi- or trilobate. Epiproct (Figure 4a), eight times longer than its widest part, basal 0.70 of dorsal margin with seven strong spines, basal 0.65 of ventral margin with seven strong spines, carinae with four strong spines, remainder of margins with scarce, minute, very fine setae, tip trilobate, with the middle lobe ending in a slender filament of $0.5 \mathrm{~mm}$ length, the dorsal and ventral lobes digitiform, roundly tipped, the ventral lobe separated from the median lobe by a deep emargination as wide as the width of the ventral lobe. Paraproct (Figure 4b), nine times longer than its widest part, basal 0.60 of dorsal margin with six strong spines, basal 0.75 of ventral margin with 22 strong spines, carinae with seven strong spines, remainder of margins with scarce, minute, very fine setae, tip bilobate, the dorsal lobe longer, ending in a filamentous tip of $0.7 \mathrm{~mm}$ length, ventral lobe digitiform, roundly tipped, separated of dorsal lobe by a deep emargination. Male cerci wider than long, globose (Figure 3a, b), female cerci conical, curved downwards, with tips slightly convergent (Figure $3 d)$.

Measurements (mm): $\quad$ Larvae only: TL 11.5-12; AL 3.8-4.5; PfL 1.1-1.5; MsfL 1.5; HtfL 1.92.0; CeL 0.1; MgL 0.5; FgL 1.10; MWh 2.3; Epiproct length 4.0, maximum width 0.5; Paraproct length 4.5 , maximum width 0.5 . The measurements correspond to males and females.

\section{Diagnosis}

Psaironeura differs from Central American Neoneura and Protoneura by the following characteristics (those of Neoneura $[N]$ and Protoneura $[P]$ in parentheses): premental seta $2+{ }_{1}$ on each side of midline $(N 1-2 ; P 1)$; pronotum extended posterolaterally forming a nipple-shaped tubercle (posterolateral corners rounded in both $N$ and $P$ ); palpal setae 6 ( $N 3-5$; P5). Femora and S7-10 with concave, roundly pointed setae ( $N$ and $P$ lacking this kind of setae); valvae of female gonapophysis about same size ( $N$ ?; $P$ central valvae longer); epiproct's tip trilobated, middle lobe filamentous; paraproct's tip bilobed ( $N$ tip acute, lacking filament; $P$ tip sharply pointed, with filament). Comparison based on the descriptions of Anjos-Santos, Pessacq, and Martins-Costa (2011) for Neoneura and Novelo-Gutiérrez (1994) for Protoneura.

\section{Key to the larvae of Central American genera of Protoneurinae}

1. Pronotum rounded on posterolateral corners; usually one premental seta to each side of midline; palpal setae $3-5$; femora and S7-10 with spiniform setae $\ldots \ldots \ldots \ldots \ldots \ldots 2$ 
1' Pronotum forming a large, conspicuous, nipple-shaped tubercle on posterolateral corners; premental setae $2+1$; palpal setae 6; femora and S7-10 with concave, roundly pointed

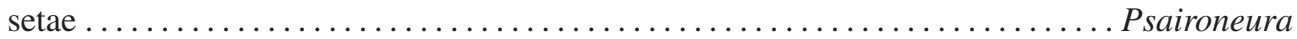

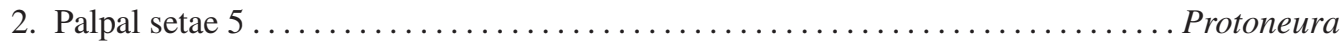

$2^{\prime}$ Palpal setae usually 3-4 (4-5 in N. aaronii, only in the north of Mexico) ........ Neoneura

\section{Habitat}

Psaironeura lives in forest streams and swamps (Esquivel Herrera 2005). In this study, larvae of $P$. angeloi were found in shady areas of shallow streams, in puddles with slow current and fine sediments, associated with leaf litter (Figure 5a, b). In the Tirimbina, it was collected in humid forest premontane transition to basal (BMH-P) and very humid tropical forest (BMH-T). Other authors report adults of this species in tropical dry forest and subtropical humid forest (Tobias-Loaiza \& Tamaris-Turizo, 2019), always in shady zones with dense vegetation.

\section{Acknowledgements}

The first author is grateful to SINAC for the collecting permit, and Yanil Bravo-Méndez for her invaluable help during fieldwork. Also to Sistema de Estudios de Posgrado UCR for financial support to carry out an internship at INECOL. Thanks are due to Dr. J. Antonio Gómez-Anaya for the images edition, and to Dr. William Haber for the species corroboration. We also thank the reviewers Dr. Diogo Vilela and Dr. Ângelo Praese Pinto for their invaluable comments and suggestions which greatly improved the manuscript; however, the final version is the responsibility of the authors.

\section{Funding}

Fieldwork was supported by R.T. COX through a stipend of investigation to the first author, and the Tirimbina Biological Reserve under the student grant ACACED.

\section{ORCID}

Jareth Román-Heracleo (D) http://orcid.org/0000-0002-3052-6201

Rodolfo Novelo-Gutiérrez (D) http://orcid.org/0000-0003-3163-2820

Monika Springer (D) http://orcid.org/0000-0003-0926-1322

\section{References}

Anjos-Santos, D., Pessacq, P., \& Martins-Costa, J. (2011). Description of the last instar larva of Neoneura kiautai Machado (Odonata: Protoneuridae). Zootaxa, 2916, 65-68. doi:10.11646/zootaxa.2916.1.6.

Corbet, P. S. (1953). A terminology for the labium of larval Odonata. The Entomologist, 86, 191-196.

Garrison, R. W., von Ellenrieder, N., \& Louton, J. A. (2010). Damselfly genera of the New World. Baltimore, MD: The Johns Hopkins University Press.

Esquivel Herrera, C. (2005). Libélulas de Mesoamérica y el Caribe-Dragonflies and damselflies of Middle America and the Caribbean. Santo Domingo de Heredia, Costa Rica: Instituto Nacional de Biodiversidad (INBio).

Lozano, F., Muzón, J., Anjos-Santos, D., \& Pessacq, P. (2018). Order Odonata, Chapter 14.6. In N. Hamada, J. H. Thorp, \& D. C. Rogers (Eds.). Keys to Neotropical Hexapoda. Thopr and Covich's Freshwater Invertebrates (Vol. 3, pp. 475-494). London: Academic Press. doi:10.1016/B978-0-12-804223-6.00020-2

Neiss, U. G., \& Hamada, N. (2014). Ordem Odonata, Chapter 14. In N. Hamada, J. L. Nessimian, \& R. B. Querino (Eds.). Insetos aquáticos na Amazônia brasileira: taxonomia, biologia e ecología (pp. 217-284). Manaus, Brasil: Editora do Instituto Nacional de Pesquisas da Amazônia (INPA).

Novelo-Gutiérrez, R. (1994). Las náyades de Protoneura aurantiaca Selys y P. cupida Calvert (Odonata: Zygoptera: Protoneuridae). Folia Entomologica Mexicana, 90, 25-31.

Pessacq, P., \& Costa, J. M. (2010). Epipleoneura angeloi (Odonata: Protoneuridae), a new species from the central region of Brazil. Zootaxa, 2721, 55-61. DOI: doi:10.11646/zootaxa.2721.1.6 
190 J. Román-Heracleo et al.

Pessacq, P., Muzón, J. \& Neiss, U. G. (2018). Order Odonata, Chapter 14. In N. Hamada, J. H. Thorp, \& D. C. Rogers (Eds.). Keys to Neotropical Hexapoda. Thopr and Covich's Freshwater Invertebrates, Vol. 3 (pp. 355-366). London: Academic Press, UK. doi:10.1016/B978-0-12-804223-6.00014

Pimenta, A. L. A, Pinto, Â. P., \& Takiya, D. M. (2019). Integrative taxonomy and phylogeny of the damselfly genus Forcepsioneura Lencioni, 1999 (Odonata: Coenagrionidae: Protoneurinae) with description of two new species from the Brazilian Atlantic Forest. Arthropod Systematics \& Phylogeny, 77(3), 397-415. doi:10.26049/ASP77-3-2019-2

Pinto, Â. P., \& Kompier, T. (2018). In honor of conservation of the Brazilian Atlantic Forest: description of two new damselflies of the genus Forcepsioneura discovered in private protected areas (Odonata: Coenagrionidae). Zoologia, 35, e21351. doi:10.3897/zoologia.35.e21351

Tennessen, K. (2016). Psaironeura angeloi, a new species of damselfly (Zygoptera: Coenagrionidae) from Central and South America. Zootaxa, 4078(1), 28-37. doi:10.5281/zenodo.266982

Tobias-Loaiza, M. J., \& Tamaris-Turizo, C. E. (2019). Odonatos de la Sierra Nevada de Santa Marta, Colombia: una lista preliminar. Revista de la Academia Colombiana de Ciencias Exactas Físicas y Naturales 43(167), 212-218. doi:10.18257/raccefyn.832

Watson, M. C. (1956). The utilization of mandibular armature in taxonomic studies of anisopterous nymphs. Transactions of the American Entomological Society, 81(3/4), 155-202. 